\title{
Caspases, Cell Death and Diabetic Nephropathy
}

\author{
ELENA BĂLĂȘESCU ${ }^{1}$, DANIELA ADRIANA ION, MIRELA CIOPLEA ${ }^{2}$, SABINA ZURAC ${ }^{2,3}$ \\ ${ }^{1}$ University of Medicine and Pharmacy, Department of Pathophysiology, Bucharest, Romania \\ ${ }^{2 " C a r o l ~ D a v i l a " ~ U n i v e r s i t y ~ o f ~ M e d i c i n e ~ a n d ~ P h a r m a c y, ~ D e p a r t m e n t ~ o f ~ P a t h o l o g y, ~ B u c h a r e s t, ~ R o m a n i a ~}$ \\ "Colentina" University Hospital, Department of Pathology
}

\begin{abstract}
Diabetic Nephropathy. In 2014 (according to data published by the World Health Organization) $9 \%$ of the global population was affected by Diabetes which was considered to be directly responsible for 1.5 million deaths just two years prior (in 2012). From the entire number of patients suffering from diabetes, approximately a quarter of them develop renal affection. Diabetic nephropathy has similar physiopathology mechanisms and ultrastructural changes in cell injury characteristics in both Type 1 and Type 2 diabetes.

Cell Death. Cell Death was less studied in the renal diabetic disease, although it could represent an important pathogenic mechanism in the appearance and progression of nephropathy. At renal level the cellular loss can be explained by several mechanisms; different stimuli with cellular lesion potential can trigger apoptosis signaling with appearance of regulatory proteins having a double role (they participate in the initiation of the apoptosis path and cell death or in the ending of this process). The types of Cell Death and their relative proportion between themselves in the renal tissue have not been completely elucidated.

Caspases. Discovered in the middle of the 1990's, Caspases are a part of the cysteine proteases family and play a role in numerous aspects of physiology (having a role in development, aging and apoptosis), but also in aspects of physiopathology of several degenerative affections, autoimmune diseases, oncologic diseases - having an important part in apoptosis, necrosis and also inflammation.
\end{abstract}

Key words: diabetic nephropathy, cell death, caspases.

\section{DIABETIC NEPHROPATHY}

The Renal Diabetic Disease is the main cause of kidney failure. In the pathogenesis of the Diabetic Nephropathy there were observed numerous risk factors, out of which the most frequently mentioned are the metabolic imbalance and the genetic susceptibility. From the point of view of the genetic predisposition it has been demonstrated that renal affection to susceptible patients may even start before the Diabetes is actually diagnosed [6]. Regarding the metabolic imbalance the risk of renal lesions occurrence is higher when the level of glucose is poor or not under control. From the clinical point of view, renal affection has as a consequence proteinuria, raising of the systemic arterial pressure and the installation of kidney failure [7]. However, it should be noted that in cases of Type 2 Diabetes there is the possibility of additional affection on the kidney by some noxious factors such as obesity, arterial hypertension, dyslipidemia and macrovascular ischemic renal disease which came independently of diabetes $[4,6]$.
Even if the metabolic and hemodynamic events are intertwined there is still debate on the way in which hemodynamic abnormalities can accelerate the development of renal ultrastructural lesions in Diabetes. The major importance of the hemodynamic changes is portrayed by the fact that hemodynamic stress can trigger metabolic disorders [4] and also by the observation of rapid deterioration of the renal function at a diabetic patient that also suffers from arterial hypertension [6].

\section{CORRELATIONS BETWEEN PATHOPHYSIOLOGICAL MECHANISMS AND ULTRASTRUCTURAL MODIFICATIONS CHARACTERISTIC OF DIABETIC NEPHROPATHY}

Chronic hyperglycemia triggers the advanced glycation end products - AGEs [8] - markers of the oxidative stress intensity - that interact through specific cellular receptors, determine the activation of NF-N $\beta$ and the protein kinase C system (PKC) the one that produces the inflammation, the growth of the extracellular matrix synthesis (ECM) and 
type IV collagen, stimulation of the cell proliferation and stimulation of the cytokine synthesis (Figure 1). Out of these, TGF- $\beta$ represents an important mediator of the renal hypertrophy and the ac- cumulation of the extracellular matrix [4], while some cytokines as $\mathrm{TNF} \alpha$ and adiponectin [9, 10] interfere with the renal disfunction through modulation of insulin resistance and cell survival.

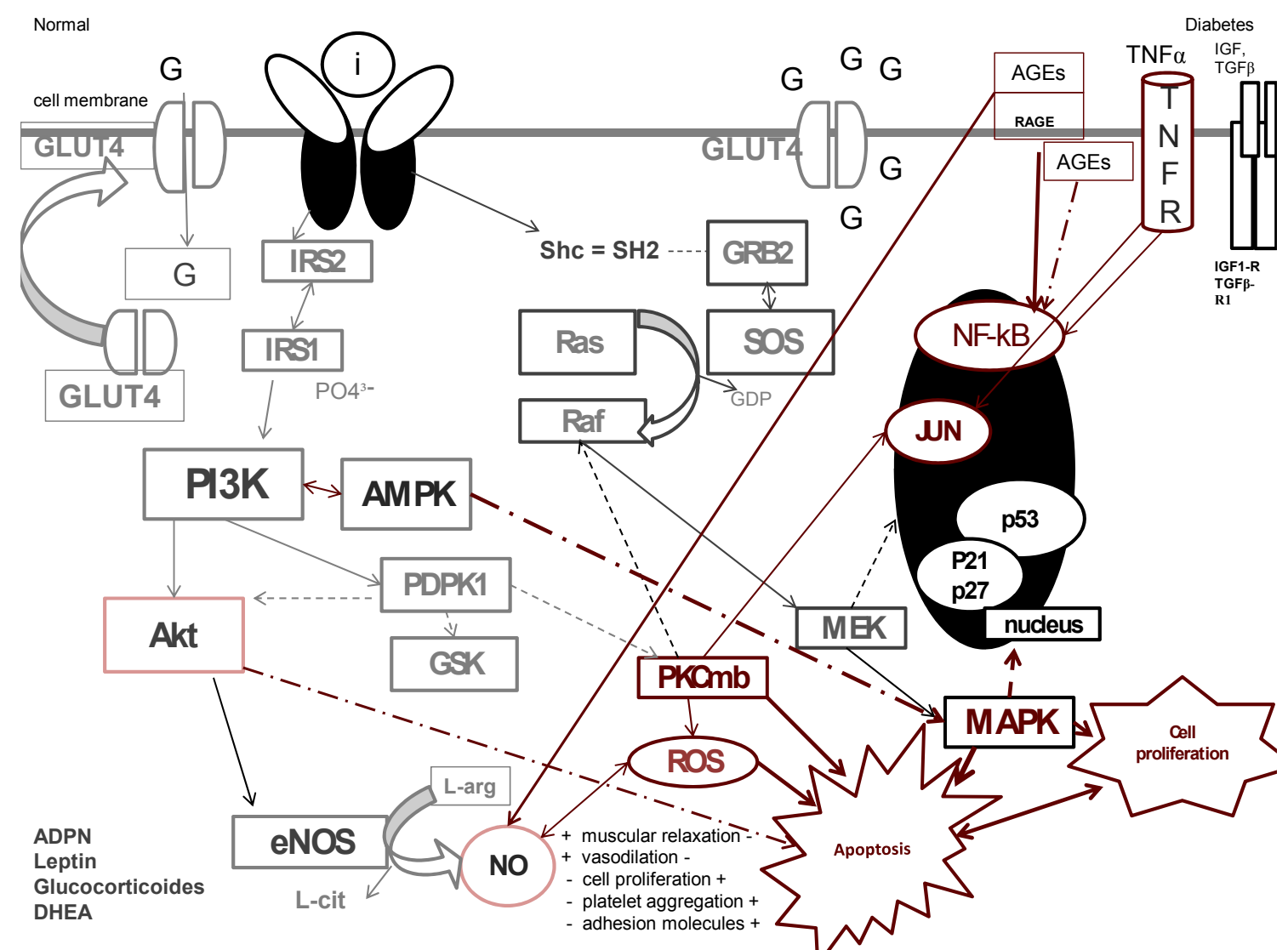

Figure 1. G - Glucose, I - Insulin, GLUT4 - Glucose transporter type 4; AMPK - 5' adenosine monophosphateactivated protein kinase; PI3K - phosphatidylinositol-3-kinase; Akt - Protein kinase B; MAPK - Mitogen-activated protein kinase; NF-kB - nuclear factor kappa-light-chain-enhancer of activated B cells; NO- nitric oxide; IR insulin receptor; IRS - Insulin receptor substrate; IGF1-R - insulin-like growth factor 1 receptor; PDPK1-3 phosphoinositide dependent protein kinase-1; eNOS - endothelialnitric oxide synthase 3; GSK - Glycogen synthase kinase 3; PKC - protein kinase C; ROS - Reactive oxygen species; GRB2 - Growth factor receptor-bound protein 2; Ras - guanosine-nucleotide-bindindg protein, member of the Ras superfamily,involved in cellular signal transduction; SOS - Son of Sevenless, guanine nucleotide exchange factors; GDP - Guanosine diphosphate; Raf serine/threonine-specific protein kinases, related to retroviral oncogenes, MEK - Mitogen-activated protein kinase; p53 - tumor suppressor p53; p21 - cyclin-dependent kinase inhibitor 1, p27 - Cyclin-dependent kinase inhibitor 1B (p27 $\left.{ }^{\text {Kip1 }}\right)$; JNK - c-Jun N-terminal kinases, member of the MAP kinase family, involved in growth, differentiation, survival, apoptosis; TNFa - tumor necrosis factor; TNFR - Tumor necrosis factor receptor; IGFR insulin-like growth factor 1 receptor, ADPN - adiponectin.

It has been shown [11] that TNF $\alpha$ can modulate the expressions of adiponectin [12] (an insulin sensitive cytokine involved in activation of the cellular fuel sensor, AMP - activated protein kinase AMPK) - in the glomerular human endothelial cells, protein TRADD (TNF-receptor 1 associated death domain) representing an indirect indicator to the status of interaction of TNF $\alpha$ ) [11].

On the other hand, hyperglycemia, mechanical stress and proteinuria play an important role in activating the rennin-angiotensin-aldosterone system
(RAAS) - and this activation can provoke most of the physiopathology changes associated with Diabetic Nephropathy. (Angiotensin II is implicated in almost every physiopathology process in the development of the Diabetic Nephropathy - hemodynamic modifications, hypertrophy, accumulation of extracellular matrix, cytokine and growing factor synthesis, generation of the reactive oxygen species (ROS), podocytes lesions, proteinuria, interstitial inflammation and fibrosis [4] - from which the therapeutic importance of blocking RAAS in the renal diabetic disease is derived). 


\section{PATHOLOGICAL CHANGES IN DIABETIC NEPHROPATHY}

Structural changes appear since the first months after the debut of the diabetic disease and they include the growth of renal volume both through glomerular (growth of the glomerular volume) and tubule interstitial interest (growth of the tubular diameter), having the basis on cellular hypertrophy and for the less part cell proliferation [4, 13]. Renal hypertrophy once built can persist for a long period of time (even years) in spite of an adequate glycemic level control; it needs to be mentioned that the renal measurements are reduced along with the evolution into renal failure [14].

Renal cells (residents or nonresidents) are stimulated by hyperglycemia and will produce humoral mediators, cytokines and growth factors, responsible for the structural modifications (the deposit of extracellular matrix) and functional modifications (the growth in permeability of the basal glomerular membrane), which, in time, lead to the development of Diabetic Nephropathy [15].

From histopathological point of view, renal affection in Diabetes can be presented in different aspects, from the typical Diabetic Nephropathy (see Table 1) to lesions that are similar to other nephropathies [4] (a proportion of 25\% up to 50\% of the renal biopsies taken from the diabetic patients could present modifications similar to those of non diabetic nephropathies: membranous nephropathy, IgA nephropathy, acute post-streptococcal glomerulonephritis, membrano-proliferative glomerulonephritis, amyloidosis $[4,15])$. The heterogeneity of the ultrastructural renal aspects in type 2 Diabetes is due to the fact that just a part of the patients present a typical diabetic glomerulopathy, the majority however having either tubulointerstitial lesions and vascular lesions more advanced than the glomerular ones or a normal renal structure barely modified $[4,16]$.

Table 1

Histopathological changes in diabetic nephropathy

\begin{tabular}{|l|l|}
\hline Glomerular structural lesions & Non glomerular structural lesions \\
\hline Glomerular hypertrophy & Renal tubular epithelial cells hypertrophy \\
\hline Increases the cell volume, cell proliferation & Thickening of the tubular basement membrane \\
\hline Thickening of the glomerular basement membrane & Tubular atrophy and interstitial fibrosis \\
\hline Podocytopenia & Armani-Ebstein lesions \\
\hline Mesangial matrix expansion & Papillary necrosis \\
\hline Diffuse glomerulosclerosis & \\
\hline Nodular glomerulosclerosis (Kimmelstein-Wilson) & \\
\hline Capsular drop & \\
\hline Fibrin caps & \\
\hline Afferent and efferent hyaline arteriosclerosis & \\
\hline
\end{tabular}

At glomerular level initially appears the hypertrophy of glomerular structures with thickening of the basement membrane, the expansion of the mesangial extracellular matrix, endothelial dysfunction. It has been suggested that the early hypertrophy of the renal cells can act as a pacemaker for the ulterior irreversible structural changes [4] (glomerulosclerosis, tubulointerstitial fibrosis), which together with the vanishing of the glomerular capillaries constitute modifications associated with the abrupt decline of the glomerular filtration rate [17].

\section{CELL HYPERTROPHY. FEATURES OF THE CELL CYCLE REGULATION IN DIABETIC NEPHROPATHY}

At the basis of the cell hypertrophy, observed in the initial state of the disease, are mechanisms of cell growth (studied through the in vitro exposure of the renal cells at high concentrations of glucoses in the culture medium) [18]. It has been demonstrated that after a short and auto limited period of proliferation that follows a process of active leaving the G0 phase of the cellular cycle, the glomerular and tubular cells exposed to hyperglycemia are retained in the G1 phase [18].

It is known that in the controlling and coordination of the proper development of the cell cycle phases the activation of the cyclin-dependent kinases (CDKs) is essential. CDKs are enzymes that are implicated in the triggering of the cell cycle events [4].

The activation of CDKs is modulated by the cyclin-dependent kinases inhibitors (CDKIs) which have the capacity to lower the kinases activity, followed by the blocking of moving to the $\mathrm{S}$ phase from the G1 phase of the cell cycle [19]. The glomerular expression of the CDKIs is stimulated by hyperglycemia, TGF- $\beta$, angiotensin II and it is 
inhibited by the treatment of angiotensin converting enzyme inhibitors (ACE inhibitors). In this sense it has been observed the attenuation of the glomerular hypertrophy as a result of the therapeutic influence of blocking the cell cycle at mice with chemical induced diabetes through ACEI treatment [4].

The retention of the glomerular and tubular cells in the G1 phase of the cell cycle is the result of gluing and inactivating the complexes of cyclinCDK by the cyclin-dependent kinase inhibitors CKIs (the most studied being $\mathrm{p} 21$ and $\mathrm{p} 27$ proteins).

The protein $\mathrm{p} 21$ (cyclin-dependent kinase inhibitor 1A, coded by the CDKN1A gene) [18] is a strong inhibitor of the kinase cyclin-dependents that glue and inhibit the activation of the CDK complexes thus having a regulating role in the progression at the G1 phase and S phase of the cell cycle. Other than the role played in blocking the cell growth, protein p21 mediates cell senescence. It interacts with the p53 protein (both implicated in the functioning of the control point of the progression from phase G1 to phase $\mathrm{S}$ ) and it regulates the replication of DNA in phase $S$ and it is implicated in fixing the DNA defects $[20,21]$. It needs to be mentioned that the activation of the response at the DNA deterioration induced by $\mathrm{p} 53$ will determine either the block of the cell cycle in the G1 phase or apoptosis [22], context in which blocking the cell cycle in G1 is partially caused by the transcriptional activation of the protein $\mathrm{p} 21$, dependent on p53. In certain conditions, the ectopic expression of the protein p 53 can induce the expression of $\mathrm{p} 21$, followed by the splintering of p21 [21] and apoptosis [22]. P21 interdependently ties itself to CDK2 and also PCNA (proliferation cell nuclear antigen, protein essential for replicating and repairing DNA [22]). When the p21 protein suffers a splintering specific of caspases, the abolition of its interaction with PCNA takes place and the important activation of $\mathrm{CDK} 2$, in this context p21 could have a role in the execution of apoptosis [21]. There are studies that showed the fact that $\mathrm{p} 21$ acts like a regulator, essential for both blocking the cell cycle and for apoptosis, while responding to the DNA altering mediated by p53 [22].

The protein p27 (cyclin-dependent kinase inhibitor 1B, also known as protein Kip1 [4]), is an enzymatic inhibitor coded by the CDKN1B gene, having a role in regulating the cycle of the cell division through stopping of slowing it down (it controls the progression of the cell cycle at G1). A series of factors of extracellular growth that promote cell division and capable of inactivating the p21 protein in different ways (affecting the synthesis, accelerated degradation or its inadequate location at cell level) will lead to reduction levels of protein $\mathrm{p} 27$ thereby activating CDK1 and CDK2 with the start of the cell cycle. In condition of persistent hyperglycemia the cells will block in the G1 phase because of the growth of the $\mathrm{p} 21$ protein synthesis through activation of the mitogen activated protein kinases and thus signaling through the MAP kinases pathway [4, 23].

Inflammation, hyperglycemia and prolonged cellular stress can lead to loss of balance in the cellular signaling pathways, with downregulation of AKT signaling and activation of MAPK-mediated apotosis (Figure 1) at renal cellular level. Apoptotic cell death due to hyperglycemia has the inflammation and reactive oxygen or nitrogen species generation as substrate [24]; increased p38 MAPK activation is also sustained by some vasoactive mediators (endothelin-1), and leads to the occurrence of ultrastructural renal lesions in diabetes and development of diabetic nephropathy through stimulation of inflammatory and profibrotic factors (ROS - reactive oxygen species, RNS - reactive nitrogen species, TNF - tumor necrosis factor, TGF transforming growth factor, PAI-1 plasminogen activator inhibitor-1).

Activated MAP kinase signaling can mediate the phosphorylation of serine residues [4] and subsequent extension of half-life of the CDK inhibitors. The accumulation of the p53, p27, p21, or of some proapoptotic members of the $\mathrm{Bcl} 2$ family and the activation of signaling through the JNK kinases path (part of the MAPK family and signalling) may represent a stimulus for triggering apoptosis as a result of the mitochondrial affection and the concurrent eliberation of cytochrome $\mathrm{c}$ and activation of APAF-1 [21] (intrinsic path of apoptosis). This leads to activation of initiator caspase 9 followed by the activation of the effective -3 and -7 caspases (promoters of ultrastructural lesions and substrate for biochemical transformations associated with apoptosis [21]: extracellular matrix accumulation, expansion of the glomerular membrane, progressive glomerulosclerosis, tubular cell hypertrophy, tubulointerstitial fibrosis [24]).

\section{THE IMPORTANCE OF CELLULAR DEPLETION IN THE DEVELOPMENT OF DIABETIC NEPHROPATHY; APOPTOSIS AND APOPTOTIC MECHANISMS}

The renal morphological lesions are determined and they are also causing cell depletion: this is the result of some mechanisms such activation of 
cellular signaling pathways involved in inflammation, increase of oxidative stress and apoptosis (which is considered the key event).

It is known that up to a certain point, the programmed cell death (apoptosis) may represent a protective mechanism [25]; in this respect it has been shown that apoptosis maintains a balance in cell populations during development, aging and also in defense reactions in diseases or noxious agents [26]. In diabetes persistent metabolic disorders will lead to a loss of balance in cellular signaling level and an abnormal cell turnover by favoring pro-apoptotic pathways and lesions progression.

After an early period of growth (by hypertrophy of glomerular and tubular cell), at renal level the loss of noble tissue appears, which is replaced by sclerosis and fibrosis. Kumar et al. have shown some evidences for apoptosis in human diabetic kidney [27] (DNA fragmentation, chromatin condensation at tubular level and in endothelial and interstitial cells). In Kumar's study, the samples of renal tissue were obtained (by percutaneous renal biopsy) from patients with diabetic nephropathy and insulin and/or angiotensinconverting enzyme inhibitor therapy. The Kumar observations were consistent with others according to which hyperglycemia and angiotensin II are apoptotic mediators [27].

In apoptosis various morphological lesions have been described, among which cell shrinkage (with smaller cell, dense cytoplasm and compacted organelles) and pyknosis (as a result of the disassembles of nuclear envelope [26], nuclear fragmentation, chromatin condensation, DNA strand breakage) are essential features of apoptosis [25]. Breakage of the cellular cytoskeleton causes external expansion of the cell membrane (blebbing), and it can lead to detachment of portions of the cytoplasm (and cytoplasmic components), giving rise to the apoptotic bodies. The apoptotic bodies are quickly phagocytosed either by specialized cells or by a neighboring cell, and so the cytoplasmic components are recycled [25], before the leakage of the dying cell contents [26]. (This differentiates cell death by apoptosis (in which the cells near the cell that dies are not affected), from the cell death by necrosis (in which multiple cells are affected (there is a local inflammatory process which is the result of cellular contents leakage and cytokine synthesis) $[25,26]$.

In diabetic kidney, cell death can occur due to loss of balance in the interaction between the members of proapoptotic and antiapoptotic Bcl-2 family [28], with down regulation of anti-apoptotic
Bcl-2 protein and the involvement of the NOS activity through Amadori products. Loss of normal kidney cells by abnormal and excessive apoptosis is a crucial pathogenic mechanism in the development of renal fibrosis [29]. Phenomena that lead to Cell Death depend on the type and the intensity of noxious signals, the type of the targeted cell [30], but also on its energetic baggage.

There are some apoptotic pathways that converge on the cell death (the extrinsic - death receptor pathway, the intrinsic - mitochondria pathway, the perforin-granzyme B pathway), having in common the activation of effector caspases, and already known consequences at the ultrastructural level (degradation of cytoskeletal proteins, formation of apoptotic bodies, DNA fragmentation, expression of phagocytic cell receptors) [25].

\section{CASPASES AND THEIR INVOLVEMENT IN DEATH PATHWAYS}

Apoptosis is frequently an energy-dependent process [25], and an important role in its emergence and development is played by proteolytic enzymes called caspases. The term "caspase" is constructed from C-symbol of cysteine which is located in the active center of the enzyme, ASP-aspartic acid (the substrate is splintered specifically right after the aspartic acid), SE-protease.

At the cellular level caspases are found as inactive enzyme precursors (named pro-caspases), being activated by cleavage of other caspases [26] in a destructing, self-amplifying and irreversible [31] proteolytic cascade. The inactive procaspases are waiting for the trigger of death, their activity ensuring a tight control of cell death program [31].

Caspases family is divided into two subfamilies [32], the first containing caspases involved in apoptosis (initiator or apical caspases 2,8,9,10 and effector caspases $3,6,7$ ), involved in inflamemation (caspases 1,4,5,12), in cytokine maturation throughout septic shock (caspase-11) [25] and in the differentiation of keratinocytes [32] (caspase 14 , which is normally expressed only in embryonic tissues [25]) and the second sub-family containing para and meta caspases (for which structural data were recently published [32]).

The initiator caspases have the ability of cleavage and consequent activation of the inactive forms of effector caspases, thereby activating them and thus triggering apoptotic pathways with rapid cell death; on the other hand, effector caspases cleave other protein substrates within the cell, to 
trigger the apoptotic process. It should be mentioned that some procaspases can aggregate and thus activate itself. The initiator caspases are composed of a pro-domain through which caspases can interact with molecules responsible for their activation. In the initiator caspases pro-domain there were described a caspase activation and a recruitment domain (CARD domain) - in caspases-2 and -9 , and a death effector domain (DED) in caspases- 8 and 10 .

From a functional perspective, caspases have a proteolytic activity that allows the recognition of nearby amino acids and also protein cleavage at aspartic acid residues; it should be noted that both cytoplasmic and nuclear proteins can be affected [25]. Their activation is under tight control of some members of the IAP (Inhibitors of apoptosis proteins) and Bcl-2 protein families, the activation process being triggerd by death signals. Among caspases cascade activators were mentioned: death receptors (TNF receptor, Fas/CD95, TRIAL receptor) [33], apoptosome formation and granzyme B (death receptors can activate caspases 8 and 10; the apoptosome is regulated by cytochrome $\mathrm{c}$ and $\mathrm{Bcl}-2$ family, and activates caspase-9, and granzyme B, released by NK cells and cytotoxic T lymphocytes, activate caspase 3 and 7) [25].

Activation of membrane death receptors (taking part in the initiation of cell death through extrinsic pathway) may lead to apoptotic and non apoptotic events [33] (it was described that anti Fas/CD95 autoantibodies can induce autophagy - a nonapoptotic type of cell death, and also a supposed cytoprotective pathway [33]).

On the cell surface activation of the death receptors occurs through different mechanisms nearby cells can increase death receptors ligand synthesis or, at the targeted cell level, due to cellular stress or damage (mitochondrial-initiated events [25]), appears an exacerbation of Fas ligand and Fas protein synthesis, events which will lead to the cell death [31].

In the extrinsic pathway of apoptosis, Fas proteins recruit intracellular adaptor proteins and thus the recruitment of procaspase- 8 occurs (after the dimerization of the death effector domain [25]). As a result the DISC complex is formed (deathinducing signaling complex), and auto-catalytic cleavage of procaspase- 8 . The execution phase of apoptosis is related by caspase- 8 activation, which acts upon executioner caspase- 3 and consequent cell death. Caspase- 3 can be activated by autocatalysis or via caspases cascade, which gives it the ability to activate other caspases.
A damaged or stressed cell can trigger death mechanisms by mitochondrial pathway (with caspases aggregation and activation within the cell [31]). Death stimuli can determine the permeabilization of the inner membrane of mitochondria,following the cytosolic release of cytochrome $\mathrm{C}$, consequent binding and activation of Apaf-1 (apoptosisactivating factor 1), and in the presence of dATP it occurs the formation of a multimolecular complex (named apoptosome [34]), which binds and activates procaspase-9.

Some Bcl-2 family members are specialized in controlling the permeability of mitochondrial membrane, thus having a role in the regulation of apoptosis events [25]. Tumor suppressor protein p53 plays an essential role in regulating $\mathrm{Bcl}-2$ proteins, with its multiple actions (activation of DNA repair proteins;blocking cell growth by stopping at the G1/S checkpoint after recognition of DNA damage; initiation of apoptosis if DNA damage is irreparable). In stressed cells a quick accumulation of $\mathrm{p} 53$ protein appeared with malfunction of p53-p21 axis with consequent regulation and the response of the DNA damage [35]. Activation of p53 is targeted by some kinases from MAP kinases family (mitogen activated protein kinases), involved in several types of stress (oxidative stress, osmotic shock, membrane damage). In diabetes, persistent hyperglycemia $[4,36]$ and ROS [36] acumulation have the ability to activate the MAPK signaling pathway with consequent posttranscriptional increase in p27 expression [4] and other factors (nuclear factor- $\kappa \mathrm{B}, \mathrm{TGF}-\beta 1$ ), reflected by morphological changes (the increased synthesis of extracellular matrix proteins [36], induced hypertrophy of mesangial cells [4]). However, there is an imbalance between p27 and p21 protein activity (it was observed the decreased expression of the p27 but not of p21, with consequent attenuation of renal hypertrophy in laboratory animals with chemically induced diabetes treated with ACE inhibitors. In this regard it is important to note that the angiotensin II blockade attenuates p27. The cell cycle arrest mediated by p27-p21 axis being essential but not sufficient for the development of cellular hypertrophy, for which complementary signals leading to increased RNA and proteins are necessary [4].

The final stage of apoptosis is represented by the execution phase, the "point of no return" in both the extrinsic and intrinsic cell death pathways. The effector or "executioner" caspases $(3,6,7)$ activate certain enzymes which degrade nuclear and cytoskeletal proteins (proteases) and nuclear 
material (endonuclease), with appearance of some distinct lesions in apoptotic cells [25].

\section{CONCLUSIONS}

In diabetes, specific morphological changes can be found at all levels of renal structures (glomerular, tubular, vascular, interstitial) causing a constellation of immunohistochemical aspects characteristic of diabetic nephropathy [6]. In this respect, from our point of view the key event is that of cell depletion. Diabetes leads to a loss of normal intracellular signaling, due to activation of MAPk pathway (as a consequence of some factors such as cellular stress, inflammation, activation of nitric oxide synthase, accumulation of cytokines and profibrotic factors) and downregulation of AKT pathway. MAPk activation contributes to the pathogenesis of diabetic nephropathy, apoptosis being proposed as a pathogenic and initiator mechanism of renal remodeling through accumulation of extracellular matrix, expansion of basement membrane of glomeruli, glomerulosclerosis, tubular cell hypertrophy and consequent fibrosis. Moreover, impairment of the mitochondria with the cytochrome $\mathrm{c}$ release triggers the intrinsic apoptosis signaling pathway (with the involvement of initiator and effector caspases).

Acknowledgment. This paper is supported by the Sectoral Operational Programme Human Resources Development (SOP HRD), financed from the European Social Fund and by the Romanian Government under the contract number POSDRU/159/1.5/S/132395 (author no. 1).

Nefropatia diabetică. În anul 2014 (conform datelor publicate de Organizația Mondială a Sănătății), 9\% din populația adultă a globului a fost afectată de diabet, care a fost considerat direct responsabil de 1,5 milioane de decese cu doar doi ani în urmă (în anul 2012). Din totalitatea pacienților cu diabet, aproximativ un sfert dezvoltă în timp afectare renală. Nefropatia diabetică are caracteristici similare din punct de vedere al mecanismelor fiziopatologice şi leziunilor ultrastructurale, atât în tipul 1 cât şi în tipul 2 de diabet zaharat. În cazurile de diabet tip 2 există însă posibilitatea ca rinichiul să fie afectat suplimentar de unii factori nocivi de tipul obezității, hipertensiunii arteriale, dislipidemiei şi bolii renale ischemice macrovasculare survenite independent de prezența diabetului.

Modificările morfologice specifice se regăsesc la nivelul tuturor structurilor renale (glomerulare, tubulare, vasculare, interstitiale), determinând o constelație de aspecte imunohistochimice caracteristice diabetului, un eveniment cheie fiind reprezentat de depleția celulară.

Moartea celulară. Moartea celulară a fost puțin studiată în boala renală diabetică, deşi ar putea reprezenta un mecanism patogenic important în apariția şi progresia nefropatiei. La nivel renal pierderea celulară poate fi explicată prin mai multe mecanisme; diferiți stimuli cu potențial lezional celular pot declanşa semnalizarea apoptotică cu apariția de proteine reglatoare cu dublu rol (participă la inițierea căilor apoptozei și la moartea celulară sau la oprirea acestui proces). Tipurile de moarte celulară precum şi proporția relativă dintre acestea în țesutul renal (apoptoză, necroză, autofagie, catastrofă mitotică), nu au fost pe deplin elucidate. Fenomenele care conduc la moartea celulară depind de tipul şi intensitatea semnalelor nocive, tipul de celulă afectată, dar şi de bagajul energetic al acesteia.

Caspazele. Descoperite la mijlocul anilor 1990, caspazele fac parte din familia cistein-proteazelor şi sunt implicate în numeroase aspecte ale fiziologiei (având rol in dezvoltare, îmbătrânire și apoptoză), dar şi ale fiziopatologiei unor afecțiuni degenerative, boli autoimune, afecțiuni oncologice - având un rol esențial atât în apoptoză şi necroză, cât şi în inflamație. Termenul de caspază provine de la C-simbol al cisteinei care este localizată în centrul activ al enzimei, ASP - acidul aspartic

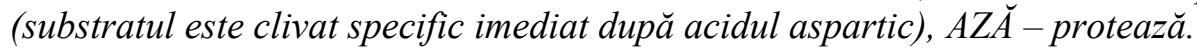

Correspondence to: Mirela Ciolpea, "Colentina" University Hospital,

Department of Pathology, 21 Stefan cel Mare str., sector 2, 020125,

Bucharest, Romania, Tel. +40213173245, Fax +40213165512

E-mail: petremireladaniela@yahoo.com 


\section{REFERENCES}

1. WHO. Diabetes Fact sheet $N^{\circ} 312$. 2015 January 2015 [cited; Available from: http://www.who.int/mediacentre/factsheets/ fs $312 / \mathrm{en} /$

2. ARIAS LF. The Kidney in Diabetes Mellitus and other Metabolic Disorders. [cited 2015201502 26]; Available from: http://www.kidneypathology.com/English_version/Diabetes_and_others.html

3. WHO. Global status report on noncommunicable diseases 2010. World Health Organization. 2011.

4. R. ALPERN, M. CAPLAN,O. MOE. Seldin and Giebisch's The Kidney; Physiology \& Pathophysiology. Academic Press; 2012. p. 2605-23.

5. ALNEMRI ES, LIVINGSTON DJ, NICHOLSON DW, SALVESEN G, THORNBERRY NA, WONG WW, et al. Human ICE/CED-3 protease nomenclature. Cell. 1996; 87(2): 171.

6. FIORETTO P, STEFFES MW, BROWN DM, MAUER SM. An overview of renal pathology in insulin-dependent diabetes mellitus in relationship to altered glomerular hemodynamics. Am J Kidney Dis. 1992; 20(6): 549-58.

7. COVIC A., COVIC M., SEGALL L., GUSBETH-TATOMIR P. Manual de Nefrologie. Polirom; 2007.

8. GOLDIN A, BECKMAN JA, SCHMIDT AM, CREAGER MA. Advanced glycation end products: sparking the development of diabetic vascular injury. Circulation. 2006; 114(6): 597-605.

9. ZHANG C, LIAO Y, Li Q, CHEN M, ZHAO Q, DENG R, et al. Recombinant adiponectin ameliorates liver ischemia reperfusion injury via activating the AMPK/eNOS pathway. PLoS One. 2013; 8(6): e66382.

10. FUJII Y, OKADA A, YASUI T, NIIMI K, HAMAMOTO S, HIROSE M, et al. Effect of adiponectin on kidney crystal formation in metabolic syndrome model mice via inhibition of inflammation and apoptosis. PLoS One. 2013; 8(4): e61343.

11. DING M, CARRAO AC, WAGNER RJ, XIE Y, JIN Y, RZUCIDLO EM, et al. Vascular smooth muscle cell-derived adiponectin: a paracrine regulator of contractile phenotype. J Mol Cell Cardiol. 2012; 52(2): 474-84.

12. QATANANI M, LAZAR MA. Mechanisms of obesity-associated insulin resistance: many choices on the menu. Genes Dev. 2007; 21(12): 1443-55.

13. WOLF G, ZIYADEH FN. Molecular mechanisms of diabetic renal hypertrophy. Kidney Int. 1999; 56(2): 393-405.

14. RIGALLEAU V, GARCIA M, LASSEUR C, LAURENT F, MONTAUDON M, RAFFAITIN C, et al. Large kidneys predict poor renal outcome in subjects with diabetes and chronic kidney disease. BMC Nephrol. 2010; 11: 3.

15. PENESCU M, MANDACHE E. The value of kidney biopsy in diabetes mellitus. Rom J Morphol Embryol. 2010; 51(1): 13-9.

16. DALLA VESTRA M, SALLER A, MAUER M, FIORETTO P. Role of mesangial expansion in the pathogenesis of diabetic nephropathy. J Nephrol. 2001; 14 Suppl 4: S51-7.

17. SUSZTAK K, RAFF AC, SCHIFFER M, BOTTINGER EP. Glucose-induced reactive oxygen species cause apoptosis of podocytes and podocyte depletion at the onset of diabetic nephropathy. Diabetes. 2006; 55(1): 225-33.

18. ZHANG Y, SHI Y, LIU Y, DONG H, LIU M, LI Y, et al. Growth pattern switch of renal cells and expression of cell cycle related proteins at the early stage of diabetic nephropathy. Biochem Biophys Res Commun. 2007; 363(1): 159-64.

19. WOLF G. Cell cycle regulation in diabetic nephropathy. Kidney Int Suppl. 2000; 77: S59-66.

20. HARPER JW, ADAMI GR, WEI N, KEYOMARSI K, ELLEDGE SJ. The p21 Cdk-interacting protein Cip1 is a potent inhibitor of G1 cyclin-dependent kinases. Cell. 1993; 75(4): 805-16.

21. ALMOND JB, COHEN GM. The proteasome: a novel target for cancer chemotherapy. Leukemia. 2002; 16(4): $433-43$.

22. GERVAIS JL, SETH P, ZHANG H. Cleavage of CDK inhibitor p21(Cip1/Waf1) by caspases is an early event during DNA damage-induced apoptosis. J Biol Chem. 1998; 273(30): 19207-12.

23. WOLF G, SCHROEDER R, ZIYADEH FN, THAISS F, ZAHNER G, STAHL RA. High glucose stimulates expression of p27Kipl in cultured mouse mesangial cells: relationship to hypertrophy. Am J Physiol. 1997; 273(3 Pt 2): F348-56.

24. RANE MJ, SONG Y, JIN S, BARATI MT, WU R, KAUSAR H, et al. Interplay between Akt and p38 MAPK pathways in the regulation of renal tubular cell apoptosis associated with diabetic nephropathy. Am J Physiol Renal Physiol. 2010; 298(1): F49-61.

25. ELMORE S. Apoptosis: a review of programmed cell death. Toxicol Pathol. 2007; 35(4): 495-516.

26. ALBERTS B JA, LEWIS J, et al., editor. Molecular Biology of the Cell. $4^{\text {th }}$ edition

ed. New York: Garland Science; 2002.

27. KUMAR D, ROBERTSON S, BURNS KD. Evidence of apoptosis in human diabetic kidney. Mol Cell Biochem. 2004; 259(1-2): 67-70.

28. HOTCHKISS RS, STRASSER A, McDUNN JE, SWANSON PE. Cell death. N Engl J Med. 2009; 361(16): $1570-83$.

29. URSEA N, editor. Esentialul in Nefrologie: Fundația Română a Rinichiului; 2002.

30. BROSIUS FC, COWARD RJ. Podocytes, signaling pathways, and vascular factors in diabetic kidney disease. Adv Chronic Kidney Dis. 2014; 21(3): 304-10.

31. CABON L, MARTINEZ-TORRES AC, SUSIN SA. Programmed cell death comes in many flavors. Med Sci (Paris). $2013 ; 29$ (12): 1117-24.

32. McLUSKEY K, MOTTRAM JC. Comparative structural analysis of the caspase family with other clan CD cysteine peptidases. Biochem J. 2015; 466(2): 219-32.

33. TOWNS R, PIETROPAOLO M, WILEY JW. Stimulation of autophagy by autoantibody-mediated activation of death receptor cascades. Autophagy. 2008; 4(5): 715-6.

34. ACEHAN D, JIANG X, MORGAN DG, HEUSER JE, WANG X, AKEY CW. Three-dimensional structure of the apoptosome: implications for assembly, procaspase-9 binding, and activation. Mol Cell. 2002; 9(2): 423-32.

35. DOLEZALOVA D, MRAZ M, BARTA T, PLEVOVA K, VINARSKY V, HOLUBCOVA Z, et al. MicroRNAs regulate p21(Waf1/Cip1) protein expression and the DNA damage response in human embryonic stem cells. Stem Cells. 2012; 30(7): $1362-72$.

36. LEE HB, YU MR, YANG Y, JIANG Z, HA H. Reactive oxygen species-regulated signaling pathways in diabetic nephropathy. J Am Soc Nephrol. 2003; 14(8 Suppl 3): S241-5.

Received April 28, 2015 